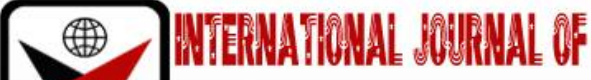

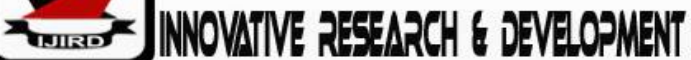

ISSN 2278-0211 (Online)

\section{Impediments to Effective Utilization of E-learning Platforms for Quality Teaching and Learning in Universities in Niger-Delta, Nigeria}

\author{
Owo Offia Tugwell \\ Ph.D. Research Student, Department of Vocational and Technology Education, \\ Rivers State University, Port Harcourt, Rivers State, Nigeria \\ Ajie Prince Maduabuchukwu \\ Lecturer, Department of Metalwork, \\ Federal College of Education (Technical), Omoku, Rivers State, Nigeria
}

\begin{abstract}
:
The Nigerian educational system is bedeviled with multifarious problems ranging from poor funding, poor service delivery, poor research and development, inadequate training facilities, unfavourable policies among others. These challenges are more pronounced in higher education than basic and secondary education. These issues already stated and many more constitute barriers to quality teaching and learning. In Nigeria, the use of e-learning for quality continuous education at higher education level is not effective due to the issues of poor information and communication technology (ICT) skills acquisition by both staff and students, irregular power supply, lack of internet connectivity, poor professional development of staff among others. This Paper entitled "Impediments to effective utilization of e-learning for quality teaching and learning in universities in Niger-Delta, Nigeria" therefore examined the factors which as barriers to effective e-learning usage for quality teaching and learning in universities in Nigeria, with a view to finding a lasting solution to the menace of poor teaching and learning which adversely affected human capacity development in the country.
\end{abstract}

Keywords: E-learning, university teaching and learning, online education, ICT

\section{Introduction}

Teaching and learning are two academic activities that go simultaneously in any formal educational institutions. It involves the coming together of a teacher and students (learners) for quality interactions through effective communications leading to knowledge transfer and information sharing. According to Adiele, Leigha and Abraham (2010), teaching entails a triadic connection between the teacher, subject matter and the student. Teaching can be regarded as the act of passing information by the teacher to the learners to boost their knowledge concerning certain phenomena, events, concepts, principles and theories. The main aim of teaching is to achieve quality learning. When the learner utilizes the knowledge gained through quality interactions with the teacher and other learners to solve practical problems, one can say that the teaching-learning exercise is effective. No meaningful learning can take place without a teacher. Hence, quality teaching brings about quality learning. A teacher is one who facilitates quality instructional delivery to students using an effective curriculum. The work of the teacher is to guide students aright in course of facilitating quality teaching and learning in class.

Learning in formal education can be described as the act of acquiring knowledge, skills and experience from an expert through a well-planned instructional curriculum leading to a change in the learners' cognitive, affective and psychomotor domains of learning. Effective learning occurs when what is being learnt is put into practice. That is, when learning brings about a change in the learners' knowledge, feelings and practical experiences. Oyeniran, Oyeniran, Oyeniyi, Ogundele and Ojo (2020) posit that the aim of learning is knowledge preservation, transmission and creative application, therefore, it is expected that the students memorize the new information during the study process and apply it appropriately on a later date. In Nigeria, teaching and learning in schools at basic, secondary and higher education levels. Higher education institutions include the universities, polytechnics, colleges of education, monotechnics, among others.

A university is an educational institution established primarily to champion human capacity development through quality teaching, research and community services. A university is known as a citadel of excellence in teaching, learning and research for human and societal development. According to Amadi and Urho (2015), the vision of universities is to become pace-setting institutions in learning, character building and service to humanity with a duty to produce competent and creative graduates of high moral standards in the society as well as championing a comprehensive development of men and women in an enabling environment through appropriate teaching, research and service to humanity, influenced 
by the constitutional ethics and culture of the nation (Odim, Annastashia \& Solomon, 2018).Universities contribute significantly to the development of the society in virtually all nooks and crannies of the globe. Universities are usually in the lead in an event of any social, economic and political challenges, by using the power of research to focus on capacities that will promote human capacity development and solve existential problems (Oyeniranet al., 2020).The goal of every tertiary institution is to impart knowledge, skills, attitude, values and norms to learners in other to bring about development in the lives of every student and for national transformation and development.

The university teachers also known as lecturers are the people who teach and conduct research in universities and research institutes with emphasis on societal development. A university lecturer therefore needs to be flexible, intelligent, unassuming, resourceful and competent in the discharge of his duties for effective training of students. According to Adieleet al. (2010), a teacher is one who features a subject specialist and an educator; as a specialist, a teacher a teacher needs to have candid professional interest in the teaching and learning of his subject or course while as an educator, he should be conversant with the skills of teaching his subject, using relevant instructional materials. However, effective training of students is anchored on the availability of human, physical and material resources in the university. Adedeji (2017) reports that human resources needed for quality higher education in Nigeria include adequately trained lecturers and non-teaching staff, administrators, security personnel, etc. The physical resources on the other hand include library facilities, staff offices, administrative building, classroom blocks, workshop facilities, technical equipment and machines while the material resources include usable and consumable facilities such as textbooks, furniture, stationeries, teaching aids, information and communication technology (ICT) devices like computers, printers, internet services, power supply, among others. These resources are needed in the university for quality teaching, learning and research. Some other factors that can hinder quality training of students in the university include poor professional development of academic and non-academic staff, inadequate funding of programmes, poor curriculum development by teachers, poor instructional methods and strategies, inadequate application of ICT in education, poor welfare of staff among others. The teachers' ability to update their knowledge about recent innovations in their field of specialization, effective utilization of ICT devices for quality instructional delivery, engagement in quality research among others are capable of enhancing the quality of university education in Nigeria. Furthermore, the use of e-learning in instructional delivery in universities in Nigeria will encourage university students to participate in online continuous education outside the four walls of the institution's classroom. Hence, the need for e-learning utilization in Nigeria's institutions of higher learning.

\section{Concept of E-Learning}

E-learning which is described as the act of sending and receiving educational instructions for knowledge accumulation and skill development via electronic media is aimed at providing a platform for students to contribute their quota to meeting their learning needs as well as progressing in their academic pursuits at their own pace. According to Oyeniranet al., (2020), the development and introduction of new communication technologies in higher education in Nigeria has given both the learners and the lecturers the privilege to search for more information as well as interact positively and progressively on educational matters from different locations. This new digitalized form of learning is referred to as e-learning. According to Akpomi, Dambo, Ikpesu, Singer, Wokocha, Ben-George and Babalola (2020), elearning makes it easier for students to upgrade their knowledge without undergoing unnecessary hardship since they can access educational materials online right in their homes. Thus, the implementation of digital technologies in higher education institutions is directed towards students' learning instead of lecturers teaching (Alexander et al., 2017; Andrews \& Haythornthwaite, 2009; Bates \&Sangra, 2011; Guri-Rosenblit, 2009; Harasim, 2000; Johnson et al., 2016). Most higher education institutions across the globe utilize the new technologies primarily for complementary purposes and not as substitutes to face-to-face encounters or for an intensive web-enhanced teaching (Bates \&Sangra, 2011;Guri-Rosenblit, 2010; Guri-Rosenblit \& Gros, 2011). Although we cannot rule out the need for traditional education in higher education, elearning comes with numerous benefits capable of contributing to the achievement of quality education in Nigeria and the world at large. Some of the benefits of e-learning include, continuous learning outside the school campus, sharing of academic experiences from peers and colleagues, easy access to important educational information, quality research among others. According to Adeoye, Adanikin and Adanikin (2020), e-learning indicates electronic method of learning associated with online learning in an interactive interface at the convenience of both the learners and lecturers. According to Eze, Chinedu-Eze and Bello(2018), e-learning education is concerned with the all-inclusive integration of modern telecommunication equipment and ICT resources into the education system for quality teaching, learning and research. Thus, E-teaching and learning which occurs on any digital platforms is aimed at establishing a framework in which teachers and students interact and communicate effectively for continuous learning and research aimed at realizing quality human capacity development.

\subsection{Benefits of E-Learning in Universities in Niger-Delta, Nigeria}

E-learning was found to have numerous benefits in higher education in Nigeria. Adeoye, Adanikin and Adanikin (2020) posit that notable applications and benefits of e-learning in the university system include, interactivity, quality content delivery and boosting of learners and lecturers' confidence in the educational sector, students' engagement in active learning among others. Some of the benefits of e-learning in higher education are discussed below:

\subsubsection{E-Learning Supports Quality Content Delivery}

Akpomiet al. (2020) report that e-learning increases performance when interactivity is prominent; improves attitude and confidence; provides instructional opportunities otherwise not available; increase opportunitiesfor students- 
constructed learning; increases mastery of technical and workforce skills; preparestudents for work when stressed as a problem-solving tool; increases the preparation ofstudents for most careers and vocations; increase emphasis on individual instruction (Akpomi, 2008). University lecturers are able to use different instructional approaches such as video, audio, text and graphical designs in any online teaching session for quality instructional delivery in such a way that the students can have better understanding of the course contents.

\subsubsection{E-Learning Enhances Active Learners' Participation in Academic Matters}

E-learning aids quality interaction among lecturers and students thereby improving interpersonal relationship among peers and lecturers. According to Guri-Rosenblit (2018), the influence of digital technologies on learning and teaching generally, and in higher education specifically, is enormous. Using e-learning platforms for academic discussions improves students' collaboration among themselves and also fosters interpersonal relationship between students and lecturers. E-learning provides flexibility and convenience; eliminates traditional barriers such as time and place; helps students to study independently and enhances students' academic achievements through effective participation in education (Bezt, 1996). E-learning helps students to construct their own learning through undistracted involvement in educational activities online. University students collaborate among themselves to find solutions to real life issues as they have wider accessibility to readily available information online.

\subsubsection{E-Learning is Cost-effective Compared to Traditional (face-to-face) Education}

E-learning can be said to be cost effective in the sense that both the learners and the lecturers do not need to meet in a physical classroom for quality information sharing and interaction. Thus, there is no need for the provision of desks, table, classroom blocks and other teaching and learning facilities which are capital-intensive. Similarly, Arkorful and Abaidoo (2014) pointed out that the cost benefit of e-learning in training students is lesser than that of physical (face-toface) contact. The value of face-to-face class contact, content development, distribution and maintenance cost are exclusively high as compared to e-learning which is of lower cost.Hence, E-learning reduces educational cost and saves more time which would have been wasted in traditional face-to-face contacts.

\subsubsection{E-Learning Gives the Learner Control over What and How to Learn}

Though numerous online educational packages are available on the internet, e-learning enables the learner (student) to decide which educational contents are relevant to the course of study he is pursuing in the university. Thus, the learner has the will-power to choose what seems profitable and beneficial to his academic advancement. GuriRosenblit (2018) opines that university students always interact and connect with other people via social media to express their views in a variety of digital platforms. E-learning enables students to study at their own pace and convenience as the lecture material is readily available online for their consultation and easy usage and again, the content delivery is quite reachable to online education and distance learning (Adeoyeet al., 2020). Students in tertiary institutions including those in universities are found to be naturally prone to online learning and as such take responsibility for their personal and educational activities while using relevant digital tools for communicating (Pappas,2017; Ubachs et al., 2017).

\subsection{Barriers to Effective Utilization of E-Learning Platforms in Nigerian Universities}

Although, adopting e-learning as a means of achieving quality continuous university education for manpower development in Nigeria is a step in the right direction, numerous challenges characterized its application and usage in universities in Niger-Delta, Nigeria. Educational policy and planning, infrastructure, language and content, capacity building and financing are some of the major challenges of e-learning in Nigeria (Nwanewezi \& Akpomi, 2009). Similarly, Akpomiet al. (2020) posit that unavailability of e-learning facilities, epileptic power supply, inadequate and in some cases, lack of internet services, poor maintenance culture of available facilities, inadequate and in some cases, lack of ICT skills, resistance to change and technophobia (fear of using technology) constitute challenges to quality e-learning application and usage in Nigerian universities. Significant challenges in the areas of policy making, planning, educational administration among others need adequate consideration to ensure increased e-learning usage in our tertiary institutions of learning. Thus, the following factors among many others constitute barriers to effective use of e-learning for quality teaching and learning in Nigerian universities:

- Inadequate ICT skills acquisition by university lecturers and students.

- Poor internet connectivity and high cost of data subscription.

- High cost of e-learning training facilities like computer labs and e-library.

- Poor electricity supply.

- Poor funding of Educational programmes.

- Poor Development of Curriculum Content by Lecturers who are not ICT-Compliant.

\subsubsection{Inadequate Skills Acquisition by Lecturers and Students}

A major constraint to quality e-learning education in Nigeria is lack of adequate ICT skills acquisition by university lecturers and students. Lecturers need ICT skills to assist learners to develop proficiency in using e-learning platform for quality learning. Students also need ICT skills to be able to flow while learning a content on digital platforms. It is obvious in recent times that for e-learning to become a dominant learning pattern, many things will be put in place. The new digital technologies need both lecturers and students to assume new responsibilities and to develop a range of new ICT skills. Several studies have clearly stated the roles which lecturers and students are expected to play when utilizing the new technologies in their teaching and learning (Alexander et al., 2017; Bates \& Sangra, 2011; Benson \& Brack, 2009). E- 
learning creates an avenue for face to face interactions between students and lecturers as well as their peers and this depends on how ICT compliant are the participants (lectures and students) of online education. Inadequate possession of information and communication technology skills by lecturers and students for quality online teaching and learning in universities in Nigeria makes e-learning usage to appear so labourious and unprofitable. Akpomiet al. (2020) posit that most university lecturers and students suffer setbacks in the area of poor acquisition of ICT skills which also affect online learning.

\subsubsection{Poor Electricity Supply}

Epileptic power supply in Nigeria is seen as an age-long problem which has affected almost every aspect of the nation's economy with no exception to the educational sector. Adeoyeet al. (2020) opine that one of the major issues affecting e-learning usage in Nigerian tertiary educational institutions is epileptic power supply. Poor electricity supply is a major challenge of e-learning administration and utilization in Nigerian universities (Akpomi et al., 2020).Poor power supply syndrome experienced in Nigerian tertiary institutions resulted in technological setbacks in many universities in Nigeria because it can disconnect students and lecturers especially those residing in rural areas from participating in online education. Also, shortage in power supply makes it difficult to power electronic gadgets used in e-learning such as smartphones, laptops and desktop computers.

\subsubsection{High Cost of Data Subscription and Poor Internet Connectivity}

One major issue affecting e-learning in Nigeria is the high cost of internet data. Getting internet connectivity for effective participation in e-learning platforms need a lot of data. The cost of purchasing the data bundle is so high in Nigeria presently which makes it uneasy for many students and lecturers to always participate in e-learning. Another issue to effective use of e-learning in universities in Nigeria is poor internet connectivity. Network providers are no longer providing quality internet services to Nigerians. This development gives much concern to both university students and lecturers particularly when it comes to video conferences where both the students and lecturers have to interact, if there is no internet connectivity, the learning processes will be halted. The cost of accessing the internet in Nigeria is still on the high side. Hence, some students find it a challenge to afford (Adeoyeet al., 2020). Poor internet connectivity and high cost of data has resulted in low attendance of students during the online classes (Akpomiet al., 2020).

\subsubsection{High Cost of E-LearningTraining Facilities and Devices}

The cost of a personal computer (PC) and Laptop are still very high in Nigeria considering the income level of an average worker in the country. Few students that are privileged to have a PC/Laptop are not connected to the internet as this do attract extra costwhich they cannot afford. This low online class attendance has also been linked to the poverty situation in the country as some families and students might not be able to afford basic needs such as food and clean water let alone the expensive gadgets or resources to sustain them for online learning. Due to the increased cost of purchasing digital devices, most students are unable to procure such which adversely affected their involvement in online education (Akpomiet al., 2020).

\subsubsection{Poor Funding of Educational Programmes in Nigerian Universities}

Poor public funding of tertiary education is a major issue within the Nigerian higher education scenes. Every now and then, institutional authorities canvass for financial support from government, organized private sectors and wellmeaning individuals for quality service delivery since the cost of higher education is enormous and gradually becoming unbearable. Most tertiary institutions in Nigeria could not deliver quality manpower development aimed at achieving societal growth and advancement due to inadequate funding of educational programmes by government (Nathaniel, Adikpe \& Terna, 2017).In the same vein, Ekundayo (2008) reports that inadequate funding of higher education in Nigerian institutions halted some capital projects which would have had great impact on the learners. Some institutions resort to engaging in business ventures and leasing of properties to raise funds for their technological programmes. Without adequate funds, staff welfare and professional development will be a mirage. Again, universities cannot procure adequate information and communication technology devices that can cater for the e-learning needs of all the undergraduate and postgraduate students in the institutions without quality funding. Thus, it becomes imperative for Nigerian universities especially those sited within the Niger-Delta region to be adequately funded to meet their core objectives of quality manpower development in Nigeria. Emmanuel, Adike and Opigo (2018), state that incessant poor funding of tertiary education in Nigeria calls for urgent attention to remedy the situation if the nation must advance educationally.

\subsubsection{Poor Development of Curriculum Content by Lecturers who are not ICT-Compliant}

Most lecturers in Nigerian Universities lack basic ICT skills. Lecturers in Nigerian Universities who lack ICT knowledge and skills find it difficult to develop quality instructional contents for e-learning. Since online education requires the usage of multi- instructional (teaching) methods that can aid students' comprehension of a given course content failure to use ICT devices effectively affects learning. So, when the teachers are not effective in the development of course contents, it adversely affects communication and quality interaction between the teacher, course content and the students thus hampers quality learning outcomes. According to Adiele et al. (2010), one of the roles of a good teacher is curriculum development. Thus, if the teacher fails in his responsibility of developing curriculum content, it implies that learning will be a mirage or merely an illusion that can never be accomplished. 


\section{Conclusion}

E-learning as a means of instructional delivery in the Nigerian university system is a newly introduced concept that is yet to have wider acceptability and usage by Nigerians owing to the barriers militating against its usage. Some identified issues acting as a barrier to quality e-learning in the universities in Niger Delta, Nigeria include poor acquisition of ICT skills by lecturers and students, poor funding of university education, poor training facilities, poor internet connectivity, high data subscription fees, poor electricity supply among others. These barriers working against effective utilization of e-learning platforms for quality university education in Nigeria need to be eliminated to achieve quality manpower development in Nigeria.

\section{Recommendations}

Effective use of e-learning platforms for quality instructional delivery in Nigerian universities depends on several

factors as clearly stated in this study. Thus, from the findings of the study, the following recommendations were suggested:

- Government should provide quality funding to universities so as to realize quality teaching, learning and research.

- Universities' management should pay serious attention to the issue of lecturers' professional development for increased productivity.

- Government should ensure improved electricity supply in universities for effective academic activities.

- Government should regulate data subscription rate imposed on Nigerians by Network providers to encourage quality online education.

\section{References}

i. Adedeji, S. A. (2017). Effectiveness of educational resource utilization in teaching Basic Technology subject in Ibadan metropolis. Journal of Nigerian Association of Teachers of Technology, 12 (1), 15-20.

ii. Adeoye, I. A., Adanikin, A. F. \& Adanikin, A. (2020). COVID-19 and e-learning: Nigeria tertiary education system experience. International Journal of Research and Innovation in Applied Science, 5 (5), 28-31.

iii. Adiele, E. E., Leigha, M. B. \& Abraham, L. N. (2010). Introduction to Teaching Profession. Port Harcourt: Harey Publication Company.

iv. Akpomi, M. E., Dambo, B. I., Ikpesu, O. C., Singer, S. A., Wokocha, K. D., Ben-George, I. \& Babalola, J. O. (2020). Educational, scientific and technological innovations for sustainable development in Nigeria. World Journal of Entrepreneurial Development Studies, 5 (1), 50-63.

v. Alexander, B., Adams-Becker, S., Cummins, M., \& Hall-Giesinger, C. (2017). Digital Literacy in Higher Education, Part II: An NMC Horizon Project Strategic Brief. Volume 3, 4, August 2017. Austin, Texas: The New Media Consortium.

vi. Amadi, E. C. \& Urho, P. (2015). Educational management planners' view of strike action and its effects on educational management in Universities in Rivers State. Singaporean Journal of Business Economics and Management Studies, 4 (7), 45-55.

vii. Andrews, R. \& Haythornthwaite, C. (Eds.). (2009). Handbook of E-Learning Research. Los Angeles: Sage

viii. Arkorful, V. \& Abaidoo, N. (2014). The role of e-learning, the advantages and disadvantages of its adoption in higher education. International Journal of Education and Research, 2(12), 397-410.

ix. Bates, A. W. \& Sangra, A. (2011). Managing Technology in Higher Education: Strategies for Transforming Teaching and Learning. San Francisco: Jossey Bass.

x. Benson, R. \& Brack, C. (2009). Developing the scholarship of teaching: What is the role of e-teaching and learning. Teaching in Higher Education, 14(1), 71-80.

xi. Betz, J. A. (1996). Computer games: Increase learning in an interactive multidisciplinary environment. Journal of Technology System, 24 (2), 195 - 205.

xii. Ekundayo, T. A. (2008). Expanding Access to Higher Education in Nigeria: The Question of Quality Control. Journal of Reforming Higher Education in Africa, 22-36.

xiii. Emmanuel, B. J., Adike, A. O. \&Opigo, M. W. (2018). Alternative Sources of Funding Technical and Vocational Education and Training Curriculum in Nigerian Tertiary Institutions. International Journal of Educational Benchmark, 9 (1), 28-35.

xiv. Eze, S. C., Chinedu-Eze, V. C. \& Bello, A. O. (2018). The utilization of e-learning facilities in the educational delivery system of Nigeria: a study of M-University. International Journal of Educational Technology in Higher Education, 15(34), 1-20.

xv. Guri-Rosenblit, S. (2009). Distance education in the digital age: Common misconceptions and challenging tasks. Journal of Distance Education, 23 (20), 105-122.

xvi. Guri-Rosenblit, S. (2010). Digital Technologies in Higher Education: Sweeping Expectations and Actual Effects. New York: Nova Science.

xvii. Guri-Rosenblit, S. \&Gros, B. (2011). E-learning: Confusing terminology, research gaps and inherent challenges. Journal of Distance Education, 25 (1).

xviii. Guri-Rosenblit, S. (2018).E-teaching in higher education: An essential prerequisite fore-learning.Journal New Approaches in Educational Research, 7 (2), 93-97.

xix. Harasim, L. (2000). Shift happens: Online education as a new paradigm in learning. Internet and Higher Education, 3 (1-2), 41-61. doi:10.1016/S1096-7516(00)00032-4

xx. Johnson, L. A., Becker, S., Cummins, M., Extrada, V., Freeman, A., \& Hall, C.(2016). NMC Horizon Report 2016: Higher Education Edition. Austin, Texas: The New Media Consortium. 
xxi. Nathaniel, A. N., Adikpe, O. S. \&Terna, T. D. (2017). Technical vocational education and training and entrepreneurship for sustainable industrialization of Benue State. Journal of Nigerian Association of Teachers of Technology, 12 (1), 1-7.

xxii. Nwanewezi, M. C. \& Akpomi, M. E. (2009). Confidential secretaries and information \& communication technology (ICT) skill competency. International Journal of Communication and Performing Arts, 1 (1), $72-77$.

xxiii. Odim, O. O., Annastashia I. A. and Solomon, A. A. (2018). Effect of Strikes on Management and Planning of Educational Activities in Nigerian Universities. Global Journal of Educational Research, 17:1-8 DOI: https://dx.doi.org/10.4314/gjedr.v17i1.1

xxiv. Oyeniran, O. A., Oyeniran, S. T., Oyeniyi, J. O., Ogundele, R. A. \&Ojo, A. O. (2020). E-Learning: Advancement in Nigerian pedagogy amid Covid-19 pandemic. International Journal of Multidisciplinary Sciences and Advanced Technology, 1,85-94.

xxv. Pappas, C. (2017, January 15). Eight best practices to createlearner-centered eLearning courses. eLearning Industry.https://elearningindustry.com/millenial-learning-needs-3-reasons-not-ignore

xxvi. Ubachs, G., Konings, L., \& Brown, M. (Eds.) (2017). The Envisioning Report for Empowering Universities. Maastricht, NL: EADTU. 